\title{
Production of Bambusa vulgaris seedlings from rhizomes under brackish water irrigation
}

\author{
Lourenço M. C. Brancoo , Claudivan F. de Lacerda ${ }^{2}$, Albanise B. Marinho' ${ }^{1}$, Carlos H. C. de Sousa ${ }^{3}$, \\ Amanda S. F. Calvet ${ }^{4} \&$ Erasto G. de Oliveira ${ }^{1}$
}

${ }^{1}$ Universidade da Integração Internacional da Lusofonia Afro-Brasileira/Instituto de Desenvolvimento Rural, Redenção, CE, Brasil. E-mail: lourenco.marreiros@unilab.edu.br (Corresponding author) - ORCID: 0000-0002-6215-4422; albanise@unilab.edu.br - ORCID: 0000-0002-8006-2011; erasto@unilab.edu.br - ORCID: 0000-0002-3781-5874

${ }^{2}$ Universidade Federal do Ceará/Departamento de Engenharia Agrícola, Fortaleza, CE, Brasil. Email: cfeitosa@ufc.br - ORCID: 0000-0002-5324-8195

${ }^{3}$ Faculdade Ieducare, Tianguá, CE, Brasil. E-mail: sousaibiapina@yahoo.com.br - ORCID: 0000-0001-9462-4647

${ }^{4}$ Universidade Federal do Ceará/Departamento de Fitotecnia, Fortaleza, CE, Brasil. E-mail: amandasmfc@gmail.com - ORCID: 0000-0001-9529-1063

\begin{abstract}
The objective of this study was to evaluate the influence of irrigation with brackish water on the production of bamboo seedlings (Bambusa vulgaris). The experiment was carried out at the Fazenda Experimental Piroás, in the municipality of Redenção, CE, Brazil (4 $14^{\prime} 53^{\prime \prime}$ S, 38 $45^{\prime} 10^{\prime}$ ” W, and altitude of $230 \mathrm{~m}$ ), in a completely randomized design with five treatments and six repetitions. The treatments consisted of five irrigation water electrical conductivity (ECw): 0.5 (control); $1.5 ; 2.5 ; 3.5$ and $4.5 \mathrm{dS} \mathrm{m}^{-1}$. At 120 days after the beginning of the application of the treatments the leaf gas exchange, relative chlorophyll index (RCI), plant height $(\mathrm{H})$, shoot dry matter (SDM), H/SDM ratio, and the concentrations of $\mathrm{Na}^{+}$and $\mathrm{K}^{+}$ in stems and leaves were evaluated. Salt tolerance indexes were calculated based on SDM, H, photosynthesis rate and RCI. The increase in the ECw reduced leaf gas exchange, and the reduction in the photosynthesis rate was caused by stomatal and non-stomatal effects. The salinity affected negatively the growth and quality of bamboo seedlings, with the greatest effects being with ECw equal to or greater than $2.5 \mathrm{dS} \mathrm{m}^{-1}$. Bamboo seedlings present $\mathrm{Na}^{+}$retention in the stems and low $\mathrm{Na}^{+} / \mathrm{K}^{+}$ratio in the leaves. Bamboo seedlings are tolerant to salinity up to $1.5 \mathrm{dS} \mathrm{m}^{-1}$, indicating that waters with this salinity can be used for seedling production of this species, without loss of growth and quality.
\end{abstract}

Key words: bamboo, salinity, salt tolerance

\section{Produção de mudas a partir de rizomas de Bambusa vulgaris sob irrigação com água salobra}

\begin{abstract}
RESUMO: Objetivou-se com este trabalho avaliar a influência da irrigação com água salobra na produção de mudas de bambu (Bambusa vulgaris). O experimento foi desenvolvido na Fazenda Experimental Piroás ( $4^{\circ} 14^{\prime}$ $53^{\prime \prime} \mathrm{S}, 38^{\circ} 45^{\prime} 10^{\prime \prime}$ W, e altitude de $230 \mathrm{~m}$ ), no município de Redenção, Ceará, no delineamento inteiramente casualizado, com seis repetições. Os tratamentos foram constituídos de cinco condutividades elétricas da água de irrigação (CEa): 0,5 (testemunha); 1,5; 2,5; 3,5 e 4,5 dS m-1. Aos 120 dias após o início da aplicação dos tratamentos foram avaliadas: trocas gasosas foliares, índice relativo de clorofila (IRC), altura das plantas $(\mathrm{H})$, produção de biomassa seca da parte aérea (MSPA), relação H/MSPA e teores de sódio e potássio nos caules e folhas. Com os dados de MSPA, H, fotossíntese e IRC foram calculados os índices de tolerância à salinidade. $\mathrm{O}$ incremento na CEa reduziu as trocas gasosas foliares, sendo a redução na taxa de fotossíntese provocada por causas estomáticas e não estomáticas. A salinidade afetou negativamente o crescimento e a qualidade das mudas de bambu, sendo os efeitos mais expressivos com valores de CEa iguais ou superiores a 2,5 dS m${ }^{-1}$. Mudas de bambu apresentam retenção de $\mathrm{Na}^{+}$nos caules e baixa relação $\mathrm{Na}^{+} / \mathrm{K}^{+}$nas folhas. As mudas de bambu são tolerantes à salinidade até $1,5 \mathrm{dS} \mathrm{m}^{-1}$, sendo um indicativo que águas com esta salinidade podem ser utilizadas na produção de mudas desta espécie, sem perdas de crescimento e de qualidade.
\end{abstract}

Palavras-chave: bambu, salinidade, tolerância à salinidade 


\section{INTRODUCTION}

Bambusa vulgaris is one of the various bamboo species found all over the world, being more common in China, Madagascar, Asia, Australia, Africa and Central and South Americas. This species has culms that are straight close to the soil and droop at the tip, being widely used for civil construction, as raw material in the manufacture of paper and in the production of biomass and energy (Ghavami \& Marinho, 2005; Ribas, 2016; Santos et al., 2016).

The most widely used form of propagation for bamboo species is the asexual method, because flowering, and consequently seed production, is a very rare phenomenon in this species. The primordial benefit in this type of propagation is the obtaining of clones with phenotypic uniformity, thus maintaining characteristics identical to parental origin; in the case of bamboo, sections of culms, lateral branches or rhizomes are used (Braga et al., 2017).

Irrigation is one of the fundamental factors for obtaining quality seedlings. However, in semiarid regions, as it is a case of the Brazilian semiarid region, part of the water sources, mainly groundwater, has limitations due to the high concentrations of salts and sodium (Holanda et al., 2016).

Bamboo is an alternative to increase biomass production in the semiarid region of Brazil, but there is a lack of information on irrigation management for this species, particularly when brackish water is used. In the case of seedling production, identifying the level of tolerance to salinity is extremely relevant, as it can serve as indicative for the use of sources of brackish water and of the capacity of this species to be established under saline conditions.

In view of the above, the present study aimed to evaluate the tolerance to salinity of bamboo seedlings produced from rhizomes, through growth and physiological evaluations.

\section{Material AND Methods}

The experiment was carried out under $50 \%$ shade net at the Piroás Experimental Farm, belonging to the Universidade de Integração Internacional da Lusofonia Afro-Brasileira (UNILAB), in the district of Barra Nova (4' $14^{\prime} 53^{\prime \prime} \mathrm{S}, 38^{\circ} 45^{\prime}$ 10 ” W, altitude of $230 \mathrm{~m}$ ), municipality of Redenção, CE, Brazil in the period from July to December 2015.

The experiment was conducted in a completely randomized design, with five treatments and six repetitions. Treatments consisted of five irrigation water electrical conductivity (ECw): 0.5 (control); $1.5 ; 2.5 ; 3.5$ and $4.5 \mathrm{dS} \mathrm{m}^{-1}$. In order to obtain the irrigation water electrical conductivity, the salts $\mathrm{NaCl}$ and $\mathrm{CaCl}_{2} .2 \mathrm{H}_{2} \mathrm{O}$, at $7: 3$ equivalent proportion, were added to the water from a reservoir located on the farm, with ECw of 0.5 $\mathrm{dS} \mathrm{m}^{-1}$. This proportion was used because it is close to that observed in many water sources in the Brazilian semiarid region (Medeiros, 1992).

Bamboo rhizomes were planted in polyethylene pots with capacity for $60 \mathrm{~L}$, at spacing of $1.0 \mathrm{~m}$ between rows and $0.80 \mathrm{~m}$ between pots in the same row. The salt treatments application started 15 days after the rhizomes were transplanted to the pots.

A drip irrigation system was installed, and irrigation management along the entire experiment was based on the climate, using the indirect method of USWB Class-A pan, which was installed close to the experimental area. The irrigation depth was applied at two-day intervals, using a pan coefficient (kp) of 0.7 and in order to replace $100 \%$ of reference evapotranspiration (ETo). Thus, it was possible to maintain the soil at field capacity and, in addition, a leaching fraction of 0.2 was applied.

At 120 days after the treatments started, fully mature leaves were evaluated for net photosynthesis (A), stomatal conductance (gs), transpiration rate (E) and internal $\mathrm{CO}_{2}$ concentration (Ci). Measurements were taken between 8 and $12 \mathrm{~h}$, with an infrared gas analyzer (Li6400XT model, Licor, USA), using an artificial radiation source of $1400 \mu \mathrm{mol} \mathrm{m}^{-2} \mathrm{~s}^{-1}$ and under natural conditions of temperature and $\mathrm{CO}_{2}$ concentration. Additionally, the relative chlorophyll index (RCI) was estimated using a portable SPAD meter (502 model, Konica Minolta, Osaka, Japan), in the same leaves used for gas exchange measurements.

After measuring their height $(\mathrm{H})$, plants were harvested, separated into stems and leaves, and dried in a forced air circulation oven at $65{ }^{\circ} \mathrm{C}$ until constant weight. Shoot dry matter (SDM) was obtained by the sum of the biomasses of the leaves and stems. Data of plant height and shoot dry matter were used to calculate the H/SDM ratio.

The dry materials of leaves and stems were ground in a Wiley-type mill (MA 340 model, Marconi, Brazil) and used to determine sodium and potassium concentrations, according to the method of Miyazawa et al. (1984). Data of $\mathrm{Na}^{+}$and $\mathrm{K}^{+}$ concentrations were used to calculate the $\mathrm{Na}^{+} / \mathrm{K}^{+}$ratio in stems and leaves.

Data of SDM, plant height, net photosynthetic rate and relative chlorophyll index were used to calculate the percentage reductions in comparison to the lowest salinity level, and the salinity tolerance levels were obtained according to Soares Filho et al. (2016).

The collected data were subjected to analysis of variance. When there was a significant effect, the data were subjected to regression analysis. Statistical analyses were carried out with the aid of the programs Excel and Assistat 7.7 Beta (Silva \& Azevedo, 2016).

\section{Results AND Discussion}

Salinity significantly influenced all variables of leaf gas exchange evaluated in this study ( $\mathrm{p} \leq 0.01)$, which showed linear responses to the increase in irrigation water electrical conductivity (ECw). There were also significant effects on growth, relative chlorophyll index, and on $\mathrm{Na}^{+}, \mathrm{K}^{+}$ concentrations and $\mathrm{Na}^{+} / \mathrm{K}^{+}$ratio $(\mathrm{p} \leq 0.01)$.

The net photosynthetic rate (A) decreased by $1.89 \mu \mathrm{mol} \mathrm{m}^{-2} \mathrm{~s}^{-1}$ per unit increase in ECw (Figure 1A). Similar results have been observed in several plant species, which showed reductions in their photosynthetic rates when subjected to salinity (GarciaSanchez et al., 2006; M'rah et al., 2006; Navarro et al., 2007; Praxedes et al., 2010; Silva et al., 2017), leading to negative effects on the production of photoassimilates and growth.

Stomatal conductance decreased by $0.017 \mathrm{~mol} \mathrm{~m}^{-2} \mathrm{~s}^{-1}$ per unit increase in ECw (Figure 1B). The reduction in gs is 

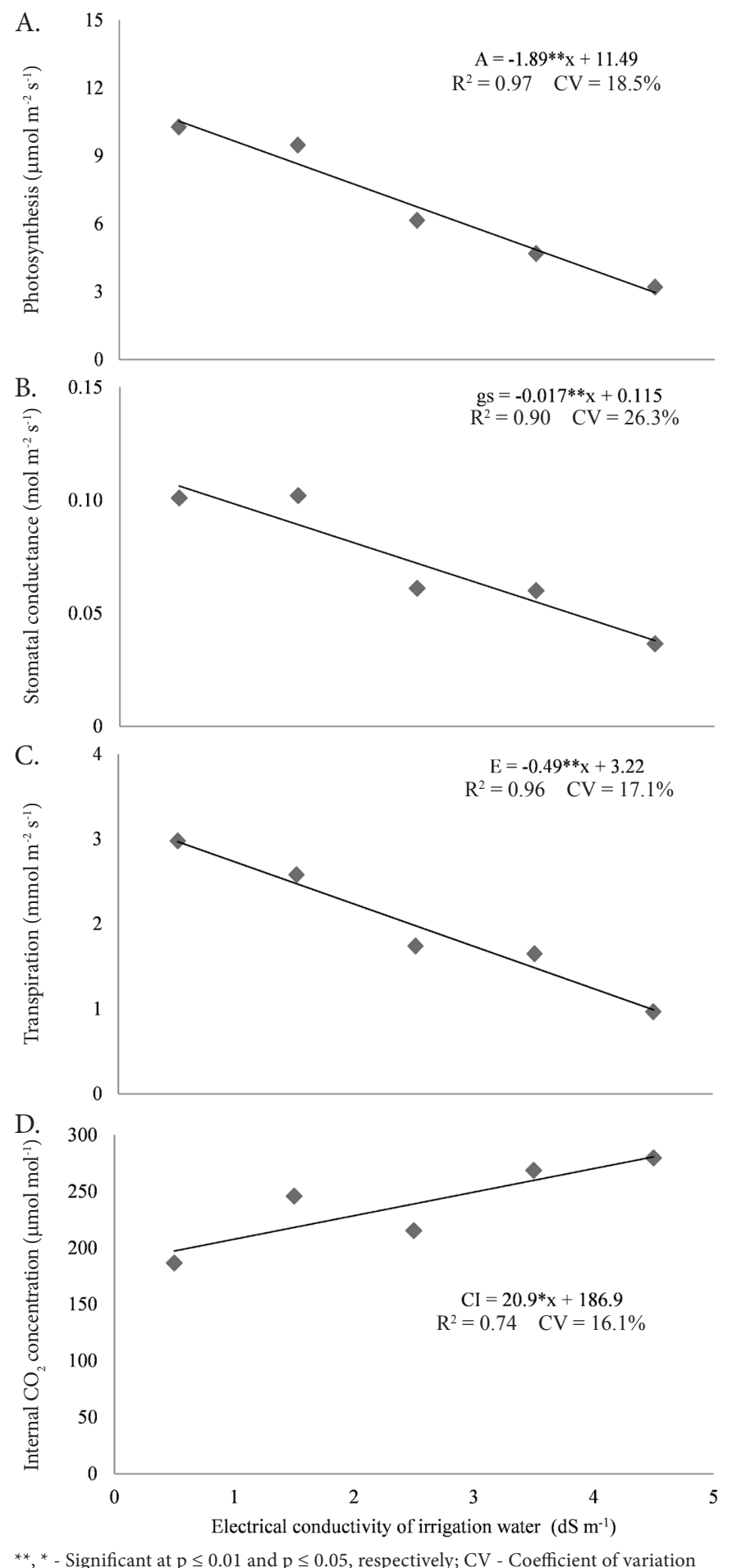

Figure 1. Net photosynthetic rate-A (A), stomatal conductancegs (B), transpiration-E (C) and internal $\mathrm{CO}_{2}$ concentration-Ci (D) in leaves of Bambusa vulgaris as a function of irrigation water electrical conductivity (ECw)

caused by the osmotic effect associated with the accumulation of salts in the soil, which hampers water absorption by roots (Ramegowda \& Kumar, 2015). As a consequence, plants decrease stomatal opening to reduce water losses to the atmosphere.

In agreement with the above-mentioned observations, the transpiration rate (E) decreased by $0.49 \mathrm{mmol} \mathrm{m}^{-2} \mathrm{~s}^{-1}$ per unit increase in ECw (Figure 1C). This result agrees with Lima et al. (2010), who report that stomatal conductance behavior (Figure 1B) determines the transpiration demand to which the leaves are potentially subjected, controlling their water loss to the environment under stress conditions (Taiz et al., 2015).

Stomatal closure constitutes a physical barrier to $\mathrm{CO}_{2}$ entry into mesophyll cells, leading to lower carboxylation rates. However, the reduction in photosynthetic rate may also be due to non-stomatal effects (Silva et al., 2017; Medeiros et al., 2018), associated with the photochemical phase and with the carbon reduction cycle (Hussain et al., 2012). The data from the present study showed that internal carbon concentration (Ci) increased linearly as the ECw (Figure 1D) increased, although there was a reduction in gs (Figure 1B). This demonstrates that the net photosynthetic rate measured at the end of the experiment (Figure 1A) was not limited by $\mathrm{CO}_{2}$ supply.

Similar results were obtained by Musyimi et al. (2007), who observed around $300 \%$ increase in $\mathrm{Ci}$ in avocado plants under saline conditions, and simultaneous reductions in photosynthetic rate. According to Lucena et al. (2012), increments in leaf tissue $\mathrm{Ci}$ may be associated with a reduction in the activity of carbon metabolism enzymes due to the sensitivity to $\mathrm{Na}^{+}$and $\mathrm{Cl}^{-}$accumulation in the leaves, resulting in phytotoxicity. It is important to emphasize that the evaluated leaves exhibited symptoms of burning (visual observation), especially at the highest ECw, which is indicative of toxic effects caused by the accumulation of salts in leaf tissues or of effects that cause leaf dehydration.

Figure 2 illustrates the data of height $(\mathrm{H})$, shoot dry matter (SDM), height/shoot dry matter ratio $(\mathrm{H} / \mathrm{SDM})$ and relative chlorophyll index (RCI).

Plant height was affected by salt stress, showing a reduction as the imposed stress increased (Figure 2A). As can be observed, the reduction in plant height became more pronounced under conditions of salinity higher than $2.5 \mathrm{dS} \mathrm{m}^{-1}$. According to Jácome et al. (2003), the most common effect of salinity on plants, in general, is the limitation of growth, due to the increase in the osmotic pressure of the medium and, consequently, reduction of water availability, affecting cell division and elongation.

With the increase in ECw, shoot dry matter production decreased according to a quadratic polynomial model (Figure 2B). Pulavarty \& Sarangi (2018), analyzing the growth of seedlings of three bamboo species under $100 \mathrm{mM}$ of $\mathrm{NaCl}$, also observed reductions in shoot biomass production and number of leaves, and the response depended on the species. These reductions in production are explained by the influence of salt stress, which can also alter the partitioning of photoassimilates between the different parts of the plants.

The increase in irrigation water salinity caused increments in the H/SDM ratio (Figure 2C). This ratio is a good indicative of the seedling survival capacity in the field; the lower the quotient obtained, the more rustic will be the seedling (Gomes et al., 2002). Therefore, the increments in H/SDM ratio, observed mainly under ECw values equal to or higher than $2.5 \mathrm{dS} \mathrm{m}^{-1}$, result in loss of seedling quality, considering their survival capacity. Similar results were observed in 'chichá' (Sterculia apetala (Jacq.) H. Karst.) seedlings (Lima et al., 2018).

The increase in salinity also caused a reduction in the relative chlorophyll index (Figure 2D). The reduction in chlorophyll concentration may have contributed to the reduction in $\mathrm{CO}_{2}$ 

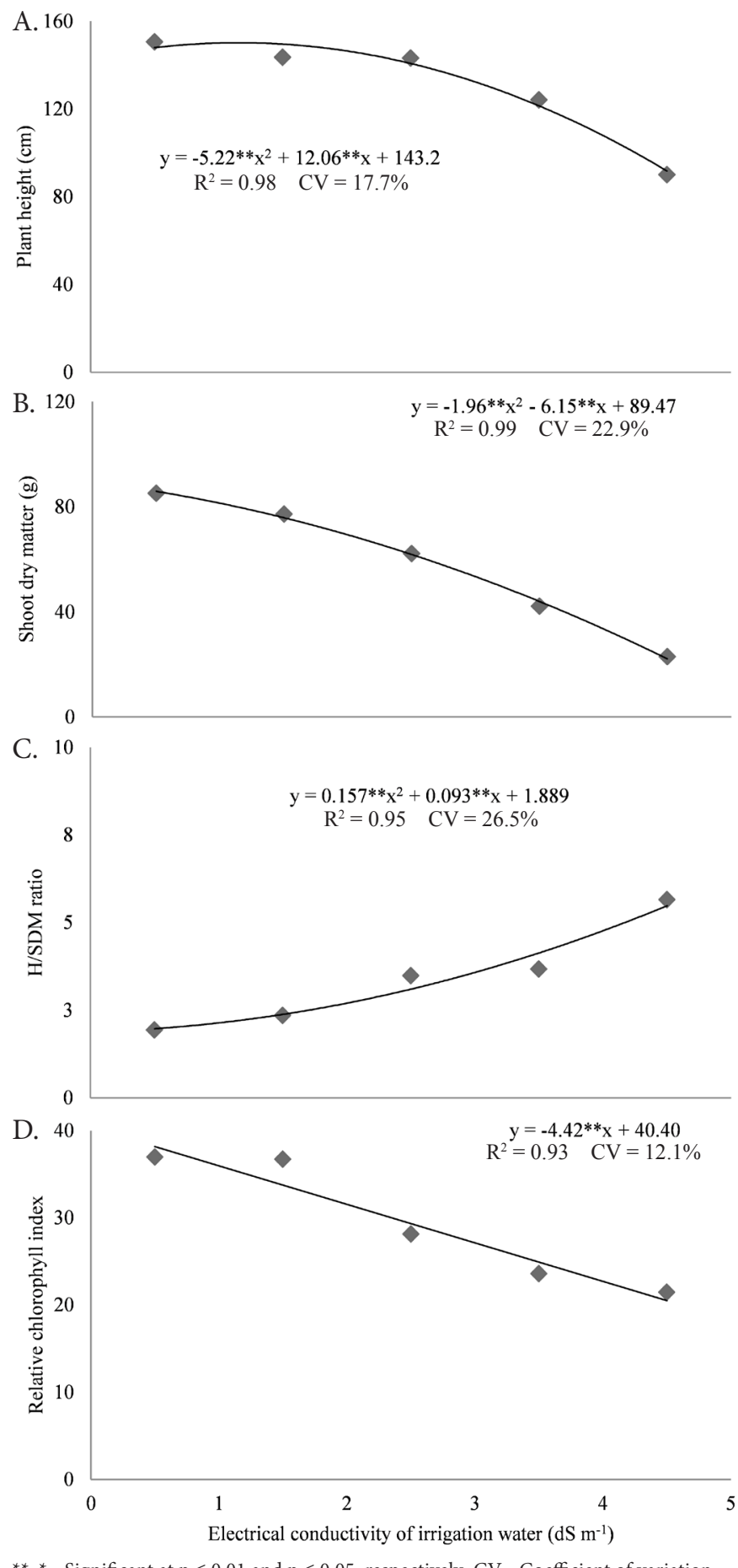

** * - Significant at $p \leq 0.01$ and $p \leq 0.05$, respectively; CV - Coefficient of variation

Figure 2. Plant height - H (A), shoot dry matter - SDM (B), height/shoot dry matter ratio - H/SDM (C) and relative chlorophyll index - RCI (D) of Bambusa vulgaris plants as a function of irrigation water electrical conductivity (ECw)

assimilation rate (Figure 1A) and it is also a factor that limits the survival capacity of seedlings under field conditions. Reduction in chlorophyll concentration under saline stress conditions has also been demonstrated in other bamboo species (Pulavarty \& Sarangi, 2018). This response may be related to the osmotic and toxic effects caused by salinity, which result in the increase of chlorophyll degradation by the enzyme chlorophyllase (Taiz et al., 2015).

The increase of ECW resulted in nutritional disorder, causing reduction in $\mathrm{K}^{+}$concentrations (Figure $3 \mathrm{~A}$ ) and increases in $\mathrm{Na}^{+}$ concentrations (Figure $3 \mathrm{~B}$ ) and in $\mathrm{Na}^{+} / \mathrm{K}^{+}$ratio (Figure $3 \mathrm{C}$ ).
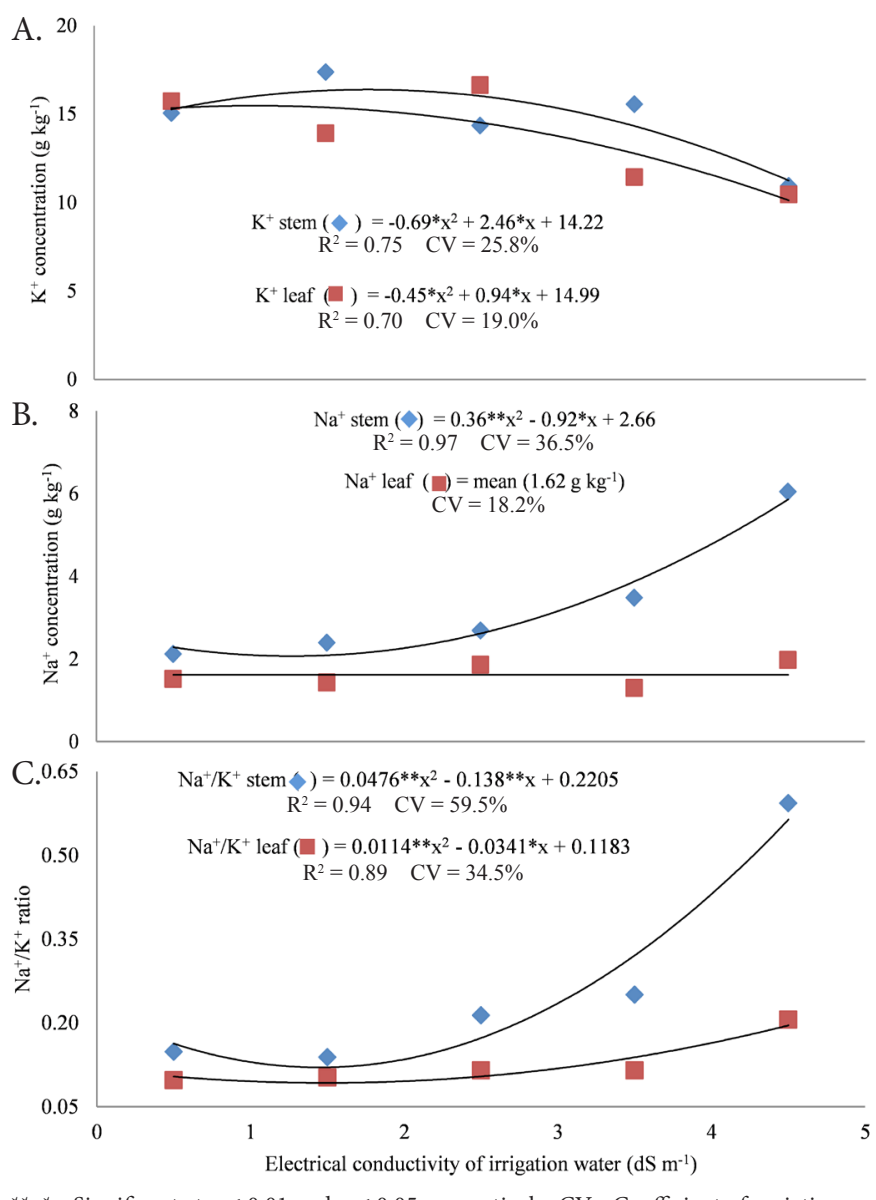

${ }^{* *},{ }^{*}$ - Significant at $\mathrm{p} \leq 0.01$ and $\mathrm{p} \leq 0.05$, respectively; $\mathrm{CV}$ - Coefficient of variation

Figure 3. Concentrations of $\mathrm{K}^{+}(\mathrm{A}), \mathrm{Na}^{+}(\mathrm{B})$ and $\mathrm{Na}^{+} / \mathrm{K}^{+}$ratio (C) in stems and leaves of Bambusa vulgaris plants as a function of irrigation water electrical conductivity $(\mathrm{ECw})$

The increments in $\mathrm{Na}^{+}$concentrations and in $\mathrm{Na}^{+} / \mathrm{K}^{+}$ratio were higher in the stems than in the leaves, suggesting the existence of a Na-retention mechanism in the stems, as observed in other species (Aquino et al., 2007). This may be explained by the fact that this ion, during its transport through the plant, i.e., from the roots to the leaves, is eliminated from the transpiration flow in order to be compartmentalized in stem tissues. In addition, the $\mathrm{Na}^{+}$ion can be readily translocated through the phloem and, consequently, the high concentrations occurring in leaves that actively transpire can be diluted by means of a redistribution throughout the plant (Lacerda et al., 2005)

Salinity tolerance has been correlated with the maintenance of adequate potassium nutrition (Tester \& Davenport, 2003), and the $\mathrm{Na}^{+} / \mathrm{K}^{+}$ratio is considered a criterion in the selection of genotypes more tolerant to salt stress (Bessa et al., 2017). $\mathrm{Na}^{+} /$ $\mathrm{K}^{+}$ratios equal to or lower than 0.6 are required for optimum metabolic efficiency in non-halophytes (Cunha et al., 2013). The $\mathrm{Na}^{+} / \mathrm{K}^{+}$ratios obtained in the present study were much higher in the stems than in the leaves, but were lower than 0.6 , indicating that this variable was not the most determinant in the reduction of plant growth and photosynthetic rate.

Several studies have reported the deleterious effect of salinity on $\mathrm{K}^{+}$concentration and $\mathrm{Na}^{+} / \mathrm{K}^{+}$ratio in the plant tissue of woody species in the seedling phase. However, these responses differ among species and the substrates used. In general, the experiments in hydroponics and using only 
$\mathrm{NaCl}$ as a stressing agent result in greater reductions in $\mathrm{K}^{+}$ concentration and greater increments in $\mathrm{Na}^{+} / \mathrm{K}^{+}$ratio, as observed for Eucalyptus species (Pulavarty et al., 2016). For cultivation in soil, as observed in plants of the 'Caatinga' (Bessa et al., 2017), or when a mixture of salts is used, as in the present study, the variations are less significant.

Table 1 shows the percentage reduction of shoot dry matter (SDM), plant height $(\mathrm{H})$, photosynthetic rate $(\mathrm{A})$ and relative chlorophyll index (RCI), compared to the lowest level of salinity applied $\left(0.5 \mathrm{dS} \mathrm{m}^{-1}\right)$, and the respective salinity tolerance indices, according to Soares Filho et al. (2016). For shoot dry matter production (SDM), bamboo was classified as tolerant (T), moderately tolerant (MT), moderately sensitive (MS) and sensitive (S), respectively, at levels of $1.5,2.5,3.5$ and $4.5 \mathrm{dS} \mathrm{m}^{-1}$.

The reduction percentages and the respective salinity tolerance classification were similar for the mean net photosynthetic rate and relative chlorophyll index (Table 1). Plant height was the variable with largest discrepancy in comparison to biomass production, so apparently it is not a good indicator of tolerance to salinity in bamboo plants. These results, however, diverge from the data of Pulavarty \& Sarangi (2018), obtained with three other species of bamboo under salt stress, which showed greater reduction in plant height than in biomass production.

Table 1. Percentage reduction of shoot dry matter (SDM), plant height $(\mathrm{H})$, photosynthetic rate $(\mathrm{A})$ and relative chlorophyll index (RCI), compared to the lowest irrigation water electrical conductivity $(\mathrm{ECw})$ applied $\left(0.5 \mathrm{dS} \mathrm{m}^{-1}\right)$, and salinity tolerance classification of Bambusa vulgaris plants subjected to increasing salinity in irrigation water

\begin{tabular}{ccccc}
\hline \multirow{3}{*}{ Variables } & \multicolumn{4}{c}{ Percentage reduction (\%) } \\
\cline { 2 - 5 } & \multicolumn{4}{c}{ ECW (dS m ${ }^{-1}$ ) } \\
\cline { 2 - 5 } & 1.5 & 2.5 & 3.5 & 4.5 \\
SDM & $9.35^{\top}$ & $27^{\mathrm{MT}}$ & $50.47^{\mathrm{MS}}$ & $73^{\mathrm{S}}$ \\
$\mathrm{H}$ & $0^{\top}$ & $1.69^{\mathrm{T}}$ & $12.94^{\top}$ & $36.56^{\mathrm{MT}}$ \\
$\mathrm{A}$ & $18^{\top}$ & $36^{\mathrm{MT}}$ & $54^{\mathrm{MS}}$ & $72^{\mathrm{S}}$ \\
$\mathrm{RCl}$ & $11.57^{\top}$ & $23.14^{\mathrm{MT}}$ & $34.72^{\mathrm{MT}}$ & $46.29^{\mathrm{MS}}$ \\
\hline
\end{tabular}

T, MT, MS, S - Tolerant, moderately tolerant, moderately sensitive and sensitive, respectively

\section{Conclusions}

1. The increase in irrigation water salinity reduced leaf gas exchanges, and the reduction in the photosynthetic rate was caused by stomatal and non-stomatal effects.

2. Salinity affected negatively the growth and quality of bamboo seedlings, with the most expressive effects at irrigation water electrical conductivity equal to or higher than $2.5 \mathrm{dS} \mathrm{m}^{-1}$.

3. Bamboo seedlings has retention of $\mathrm{Na}^{+}$in the stems and low $\mathrm{Na}^{+} / \mathrm{K}^{+}$ratio in the leaves.

4. Bamboo seedlings proved to be tolerant to salinity up to $1.5 \mathrm{dS} \mathrm{m}^{-1}$, which is an indication that water with this salinity level can be used in the production of seedlings of this species, without loss of growth and quality.

\section{ACKNOWLedgements}

Acknowledgments are due to Conselho Nacional de Desenvolvimento Científico e Tecnológico (CNPq), Instituto
Nacional de Ciência e Tecnologia em Salinidade (INCTSal), Universidade Federal do Ceará (UFC) and Universidade da Integração Internacional da Lusofonia Afro-Brasileira (Unilab), Brazil, which provided financial support and the necessary infrastructure for conducting this research.

\section{Literature Cited}

Aquino, A. J. S. de; Lacerda, C. F. de; Bezerra, M. A.; Gomes Filho, E.; Costa, R. N. T. Crescimento, partição de matéria seca e retenção de $\mathrm{Na}^{+}, \mathrm{K}^{+}$e $\mathrm{Cl}^{-}$em dois genótipos de sorgo irrigados com águas salinas. Revista Brasileira de Ciência do Solo, v.31, p.961-971, 2007. https://doi.org/10.1590/S0100-06832007000500013

Bessa, M. C.; Lacerda, C. F. de; Amorim, A. V.; Bezerra, A. M. E.; Lima, A. D. Mechanisms of salt tolerance in seedlings of six woody native species of the Brazilian semi-arid. Revista Ciência Agronômica, v.48, p.157-165, 2017. https://doi. org/10.5935/1806-6690.20170018

Braga, R. M.; Santos, K. R.; Molina, R. A. R.; Nieri, E. M.; Melo, L. A. Propagação vegetativa de Bambusa vulgaris. Pesquisa Florestal Brasileira, v.37, p.229-234, 2017. https://doi.org/10.4336/2017. pfb.37.90.1352

Cunha, P. C. de; Mendes, B. S. de S.; Oliveira Filho, R. A. de; Camara, T. R.; Willadino, L. G. Crescimento, síntese de solutos orgânicos e equilíbrio iônico de plântulas de pinhão-manso sob estresse salino. Revista Caatinga, v.26, p.46-52, 2013.

García-Sanchez, F.; Syversten, J. P.; Martínez, V.; Melgar, J. C. Salinity tolerance of 'Valencia' orange trees on rootstocks with contrasting salt tolerance is not improved by moderate shade. Journal of Experimental Botany, v.57, p.3697-3706, 2006. https://doi. org/10.1093/jxb/erl121

Ghavami, K.; Marinho, A. B. Propriedades físicas e mecânicas do colmo inteiro do bambu da espécie Guadua angustifolia. Revista Brasileira de Engenharia Agrícola e Ambiental, v.9, p.107-114, 2005. https://doi.org/10.1590/S1415-43662005000100016

Gomes, J. M.; Couto, L.; Leite, H. G.; Xavier, A.; Garcia, S. L. R. Parâmetros morfológicos na avaliação da qualidade de mudas de Eucalyptus grandis. Revista Árvore, v.26, p.655-664, 2002. https:// doi.org/10.1590/S0100-67622002000600002

Holanda, J. S. de; Amorim, J. R. A. de; Ferreira Neto, M.; Holanda, A. C.; Sá, F. V. Qualidade da água para irrigação. In: Gheyi, H. R.; Dias, N. da S.; Lacerda, C. F. de; Gomes Filho, E. 2.ed. Manejo da salinidade na agricultura: Estudos básicos e aplicados. Fortaleza: INCTSal, 2016. Cap.4, p.35-47.

Hussain, S.; Luro, F.; Costantino, G.; Ollitrault, P.; Morillon, R. Physiological analysis of salt stress behavior of citrus species and genera: Low chloride accumulation as an indicator of salt tolerance. South African Journal of Botany, v.81, p.103-112, 2012. https://doi.org/10.1016/j.sajb.2012.06.004

Jácome, A. G.; Oliveira, R. H. de; Fernandes, P. D.; Gheyi, H. R.; Souza, A. P. de; Gonçalves, A. C. A. Crescimento de genótipos de algodoeiro em função da salinidade da água de irrigação. Acta Scientiarum. Agronomy, v.25, p.305-313, 2003. https://doi. org/10.4025/actasciagron.v25i2.1904

Lacerda, C. F.; Cambraia, J.; Oliva, M. A.; Ruiz, H. A. Changes in growth and in solute concentrations in sorghum leaves and roots during salt stress recovery. Environmental and Experimental Botany, v.54, p.69-76, 2005. https://doi.org/10.1016/j.envexpbot.2004.06.004 
Lima, B. L. de C.; Lacerda, C. F. de; Ferreira Neto, M.; Campelo, D. de H.; Silva, J. A. da; Ortiz, P. F. S.; Bezerra, A. M. E. Light availability and salt stress on hazel sterculia seedlings. Floresta e Ambiente, v.25, p.2-8, 2018. https://doi.org/10.1590/2179-8087.056717

Lima, M. de A.; Bezerra, M. A.; Gomes Filho, E.; Pinto, C. de M.; Enéas Filho, J. Trocas gasosas em folhas de sol e sombreadas de cajueiro anão em diferentes regimes hídricos. Revista Ciência Agronômica, v.41, p.654-663, 2010. https://doi.org/10.1590/ S1806-66902010000400020

Lucena, C. C. de; Siqueira, D. L. de; Martinez, H. E. P.; Cecon, P. R. Efeito do estresse salino na absorção de nutrientes em mangueira. Revista Brasileira de Fruticultura, v.34, p.297-308, 2012. https://doi.org/10.1590/S0100-29452012000100039

Medeiros, J. F. de. Qualidade da água de irrigação e evolução da salinidade nas propriedades assistidas pelo GAT nos Estados do RN, PB e CE. Campina Grande: UFPB, 1992. 173p. Dissertação Mestrado

Medeiros, W. J. F. de; Oliveira, F. I. F. de; Lacerda, C. F. de; Sousa, C. H. C. de; Cavalcante, L. F.; Silva, A. R. A. da; Ferreira, J. F. da S. Isolated and combined effects of soil salinity and waterlogging in seedlings of 'Green Dwarf' coconut. Semina: Ciências Agrárias, v.39, p.1459-1468, 2018. https://doi.org/10.5433/16790359.2018v39n4p1459

Miyazawa, M.; Pavan, M. A.; Bloch, M. F. M. Avaliação de métodos com e sem digestão para extração de elementos em tecidos de plantas. Ciência e Cultura, v.36, p.1953-1958, 1984.

M'rah, S.; Ouerghi, Z.; Berthomieu, C.; Havaux, M.; Jungas, C.; Hajji, M.; Grignon, C.; Lachaâl, M. Effects of $\mathrm{NaCl}$ on the growth, ion accumulation and photosynthetic parameters of Thellungiella halophila. Journal of Plant Physiology, v.163. p.1022-1031, 2006. https://doi.org/10.1016/j.jplph.2005.07.015

Musyimi, D. M.; Netondo, G. W.; Oum, A. G. Effects of salinity on gas exchange and nutrients uptake in avocados. Journal of Biological Sciences, v.7, p.496-505, 2007. https://doi.org/10.3923/ jbs.2007.496.505

Navarro, A.; Bañon, S.; Olmos, E.; Sánchez-Blanco, M. J. Effects of sodium chloride on water potential components, hydraulic conductivity, gas exchange and leaf ultrastructure of Arbutus unedo plants. Plant Science, v.172, p.473-480, 2007. https://doi. org/10.1016/j.plantsci.2006.10.006

Praxedes, S. C.; Lacerda, C. F. de; Matta, F. M. da; Prisco, J. T.; Gomes Filho, E. Salt tolerance is associated with differences in ion accumulation, biomass allocation and photosynthesis in cowpea cultivars. Journal of Agronomy and Crop Science, v.196, p.193204. 2010. https://doi.org/10.1111/j.1439-037X.2009.00412.x
Pulavarty, A.; Kukde, S.; Shinde, V. M.; Sarangi1, B. K. Morphological, physiological and biochemical adaptations of Eucalyptus citriodora seedlings under $\mathrm{NaCl}$ stress in hydroponic conditions. Acta Physiologia Plantarum, v.38, p.1-12, 2016. https://doi. org/10.1007/s11738-015-2042-1

Pulavarty, A.; Sarangi, B. K. Screening bamboo species for salt tolerance using growth parameters, physiological response and osmolytes accumulation as effective indicators. Chemistry and Ecology, v.34, p.340-354, 2018. https://doi.org/10.1080/027575 40.2018.1427227

Ramegowda, V.; Kumar, S. M. The interactive effects of simultaneous biotic and abiotic stresses on plants: Mechanistic understanding from drought and pathogen combination. Journal of Plant Physiology, v.176, p.47-54, 2015. https://doi.org/10.1016/j. jplph.2014.11.008

Ribas, R. P. Bambu: Planta de grande potencial no desenvolvimento sustentável. 2016. Available on: <https://mac.arq.br/wp-content/ uploads/2016/03/bambu-desenvolvimento-sustentavel.pdf > Accessed on: Ago. 2018.

Santos, D. R. S.; Sette Junior, C. R.; Silva, M. F.; Yamaji, F. M.; Almeida, R. A. Potencial de espécies de bambu como fonte energética. Scientia Forestalis, v.44, p.751-758, 2016. https:/doi. org/10.18671/scifor.v44n111.21

Silva, A. R. A. da; Bezerra, F. M. L.; Lacerda, C. F. de; Sousa, C. H. C. de; Bezerra, M. A. Physiological responses of dwarf coconut plants under water deficit in salt-affected soils. Revista Caatinga, v.30, p.447-457, 2017. https://doi.org/10.1590/198321252017v30n220rc

Silva, F. de. A. S.; Azevedo, C. A. V. de. The Assistat software version 7.7 and its use in the analysis of experimental data. African Journal of Agricultural Research, v.11, p.3733-3740, 2016. https:/doi. org/10.5897/AJAR2016.11522

Soares Filho, W. S.; Gheyi, H. R.; Brito, M. E. B; Nobre, R. G.; Fernandes, P. D.; Miranda, R. S. Melhoramento genético vegetal e seleção de cultivares tolerantes à salinidade. In: Gheyi, H. R.; Dias, N. da S.; Lacerda, C. F. de; Gomes Filho, E. (eds.). Manejo da salinidade na agricultura: Estudos básicos e aplicados Fortaleza: INCTSal, 2016. Cap.17, p.259-271.

Taiz, L.; Zeiger, E.; Møller, I. M.; Murphy, A. Plant physiology and development. 6.ed. Sunderland: Sinauer Associates, 2015. 761p.

Tester, M.; Davenport, R. $\mathrm{Na}^{+}$tolerance and $\mathrm{Na}^{+}$transport in higher plants. Annals of Botany, v.91, p.503-527, 2003. https://doi. org/10.1093/aob/mcg058 